\title{
P.DOM-WT1-126 DNA Vaccine
}

National Cancer Institute

\section{Source}

National Cancer Institute. p.DOM-WT1-126 DNA Vaccine. NCI Thesaurus. Code C96738.

A fusion DNA vaccine containing the first domain of fragment $\mathrm{C}(\mathrm{FrC})$ of tetanus toxin (TT865-1120) (p.DOM) fused to the human Wilms' Tumor gene-1 (WT 1)-derived MHC class I-binding epitope WT 1.126, with potential antitumor activity. Upon vaccination with p.DOM-WT 1-126 DNA and subsequent electroporation, this vaccine may induce a WT1 epitope-specific cytotoxic T-lymphocyte (CTL) response against WT 1 expressing cells, resulting in cell lysis and inhibition of cancer cell proliferation in WT 1-overexpressing cancer cells. WT 1, a tumor associated antigen, is overexpressed in most types of leukemia and in a variety of solid cancers. The FrC of tetanus toxin contains the MHC IIbinding sequence, p30, which induces T-helper cell activation for long-lasting immunity. 